\title{
INFLUENCE OF THE "MAGNETOFOOD" FOOD SUPPLEMENT ON THE STRUCTURAL AND MECHANICAL PROPERTIES OF MOLDED FRUIT JELLY WITH VARIOUS STRUCTURE-FORMING AGENTS
}

\author{
I. V. TSYKHANOVSKA ${ }^{1 *}$, V. V. YEVLASH ${ }^{2}$, B. M. KHAMITOVA ${ }^{3}$, K. A. URAZBAIEVA ${ }^{3}$, \\ O. V. ALEKSANDROVI , N. S. KAIDA ${ }^{1}$
}

\author{
${ }^{1}$ Food and Chemical Technologies Department, Ukrainian Engineering Pedagogics Academy, Kharkiv, UKRAINE \\ ${ }^{2}$ Chemistry, Microbiology and Food Hygiene Department, Kharkiv State University of Food Technology and Trade, Kharkiv, \\ UKRAINE \\ ${ }^{3}$ Food Engineering Department, M. Auezov South Kazakhstan State University, Shymkent, KAZAKHSTAN \\ *e-mail: cikhanovskaja@gmail.com
}

\begin{abstract}
Development of resource- and energy-saving technologies for the production of high-quality jelly and pastille products with an extended shelf life is one of the most urgent challenges of the modern confectionery industry. It is proposed to use the "Magnetofood" mineral food supplement, which holds a high functional and technological potential and may independently form the structural and mechanical properties of jelly pastes, and also affect the gelling agents, entering into chemical and electrostatic interactions therewith. Therefore, the "Magnetofood" food supplement may influence several technological properties in the food jelly system at once: acting as a stabilizer, a thickener, a gelling agent, while improving the quality, consumer properties and extending the shelf life of molded fruit jelly products. The aim of the study is to improve the structural and mechanical properties of molded fruit jelly products by introducing the "Magnetofood" food supplement. Standard and generally accepted methods were used in the course of structural and mechanical studies (viscosity and thixotropic characteristics on the Reotest-2 rotation viscometer, strength characteristics on the AR-4/1 penetrometers). It has been established that the introduction of the "Magnetofood" food supplement into jelly pastes in the amount of $0.15 \%$ of the total weight of raw material improves the consistency, structure, strength and form: the degree of structuring and viscosity of the jelly pastes increases over the entire shear stress range (1.5-40 $\left.\mathrm{s}^{-1}\right) 2.9$ times for pastes on agar and 1.85 times for pastes on pectin; the temperature effect on the effective viscosity of jelly pastes is slowed down by (50-75) $\mathrm{Pa} \cdot \mathrm{s}$ on average, destruction processes are also slowed down 1.1 times, and the recovery processes of the jelly structure after the mechanical effect ceases are accelerated by $3.8 \%$, increasing its thixotropic ability by $7.5 \%$ in jelly pastes on agar and by $6.0 \%$ in jelly pastes on pectin; jelly strength on agar increases by (10-12)\%, and by (7-9)\% on pectin; the speed of structurization of jelly pastes on agar increases by a factor of 1.3-1.7, and by a factor of 1.1-1.6 on pectin.
\end{abstract}

Keywords: fruit jelly; jelly pastes; "Magnetofood" food supplement; structural and mechanical properties

\section{ВПЛИВ ХАРЧОВОЇ ДОБАВКИ “МАГНЕТОФУД” НА СТРУКТУРНО-МЕХАНІЧНІ ВЛАСТИВОСТІ ФОРМОВОГО ЖЕЛЕЙНОГО МАРМЕЛАДУ З РІЗНИМИ СТРУКТУРОУТВОРЮВАЧАМИ}

\author{
I. В. ЦИХАНОВСЬКА ${ }^{*}$, В. В. СВЛАШ ${ }^{2}$, Б. М. ХАМІТОВА ${ }^{3}$, К. А. УРАЗБАСВА ${ }^{3}$, \\ О. В. АЛЕКСАНДРОВ ${ }^{1}$, Н. С. КАЙДА
}

${ }^{1}$ кафедра Харчових та хімічних технологій, Українська інженерно-педагогічна академія, м. Харків, УКРАЇНА
2 кафедра Хімї, мікробіологї та гігієни харчування, Харківський державний університет харчування та торгівлі, м. Харків,
УКРАЇНА
${ }_{3}^{3}$ кафедра Харчова інженерія, Південно-Казахстанський державний університет ім. М. Ауезова, м. Шимкент, КАЗАХСТАН

АНОТАЦІЯ Однією з актуальних проблем сучасної кондитерської промисловості є розробка ресурсо- $і$ енергозберігаючих технологій виробництва високоякісних мармеладо-пастильних виробів зі збільщеним терміном придатності. Пропонується використання мінеральної харчової добавки "Магнетофуд", яка володіє високим функціонально-технологічним потенціалом і може як самостійно формувати структурно-механічні властивості желейних мас, так $i$ впливати на гелеутворювач, вступаючи з ним в хімічні і електростатичні взаємодіі. Тому, харчова добавка “Магнетофуд” може впливати відразу на кілька технологічних властивостей в харчовій желейної системі: бути стабілізатором, загусником, драглеутворювачем, при цьому покращуючи якість, споживчі властивості і продовжуючи терміни зберігання формового желейного мармеладу. Метою дослідження є покращення структурно-механічних властивостей формового желейного мармеладу шияхом введення харчової добавки “Магнетофуд". Під час проведення структурно-механічних (в'язкостних $i$ тиксотропних характеристик на ротаційному віскозиметрі Реотест-2, міцності на пенетрометри АР-4/1) досліджень були використані загальноприйняті та стандартні методики. Встановлено, щчо введення харчової добавки "Магнетофуд" в желейні маси в кількості 0,15\% до маси сировини покращує консистенцію, структуру, міџність і форму: підвищується ступінь структурування і в'язкість желейних мас у всьому діапазоні напруги зсуву $\left(1,5-40 c^{-1}\right)$ в 2,9 рази - для мас на агарі $i$ в 1,85 раз - для мас на пектині; сповільнюється вплив температури на ефективну в'язкість желейних мас в середньому на (50-75) Па·с, а також процеси руйнування в 1,1 рази і прискорюються процеси відновлення желейної структури після 
припинення механічного впливу на 3,8\%, підвищуючи ї̈ здатність до тиксотропї̈ на 7,5 \% в желейних масах на агарі $і$ на 6,0\% - на пектині; збільиується міиність студню на агарі на (10-12) \%, на пектині - на (7-9) \%; зростає швидкість структурування желейних мас на агарі в 1,3-1,7 разів, а на пектині в 1,1-1,6 разів.

Ключові слова: желейний мармелад; желейні маси; харчова добавка “Магнетофуд”; структурно-механічні властивості

\section{Introduction}

Fruit jelly belongs to the sugar confectionery group of products, with a distinguished gelatinous consistency. In the modern food market, fruit jelly products occupy the third place of honor among confectionery products in terms of popularity, second only to the recognized confectionery industry leaders chocolate products and caramel and candy products. Currently, mold and carved fruit jelly has become most widespread in Ukraine and other countries.

Fruit jelly products stand out among the multitude of confectionery products with their elastic, gelatinous consistency due to the use of gelling agents, consistency regulators, and their combinations (gelatin, agar, pectin, carrageenan, alginates, galactomannans, etc.). In our country, such gelling agents as agar and pectin are widely used in the fruit jelly production technology. It is worth noting that the use of expensive imported gelling agents, such as pectin, agar, xanthan, gum arabic and carrageenan increases the costs of production of finished products.

Fruit jelly products are obtained by boiling down the solution with gelling agents, granulated sugar and molasses, followed by the introduction of various additives (food acids, dyes, flavors, modifying salts) into the cooled mass [1-4]. Today, in the face of fierce competition, the manufacturers are in constant search for new forms, tastes and even new types of fruit jelly products, developing and improving their recipes and technologies; using natural (fruit juices, puree) and synthetic (food additives, enhancers) ingredients, imparting useful properties and strong consumer attributes to the finished products [4-6].

Thus, introduction of innovative technologies to expand the range, consistent with market demand and the use of new raw materials, making it possible to alter or regulate the structure of semi-finished and finished products, while improving their quality indicators, is among the priority areas for improving the range and methods of producing fruit jelly products [6-8].

There has been a significant body of research on the search for new low cost gelling components that do not cause deterioration of the normative structural and mechanical, physical and chemical, and organoleptic indicators of jelly masses and finished products, as well as for partial or complete replacement of traditional gelling agents, agar and pectin in particular - imported products with high cost of production [7-12].

When selecting a gelling agent, one should take into account the specifics of the fruit jelly product manufacture based on the gelatinization process, ensuring the stability and effectiveness of which being the main technological task $[10,11]$. Obtaining the desired texture of fruit jelly products, which is a combination of texture and structure - is always influenced by many factors introduced by the recipe components. Therefore, when selecting a gelling agent that contribute to the creation of specified texture characteristics most effectively, it is necessary to take their functional and technological properties into account.

This study explores the possibility of using the "Magnetofood" food supplement [Patent UA No. 126502, MPK A 23L 13/40, A23L 33/10. "Magnetofood" food supplement] as a structure-forming additive and stabilizer of jelly pastes. "Magnetofood" food additive isfinely divided powder with a particle size of $\sim 80 \mathrm{~nm}$ and low cost of $250 \mathrm{UAH} / \mathrm{kg}$ [13].

Nano-objects, which include "Magnetofood", have great potential and are able to form new functional and technological properties of various food systems [14-17]. Interaction of "Magnetofood" with food substances (proteins, proteids, carbohydrates, water) is a complex of composite chemical and electrostatic interactions. Supramolecular organization of nanoparticles "MagnetoFood" and organic matrix structure plays an important role in this process. The result is the formation of spatial nanostructures, significantly affecting the functional and technological properties of raw materials and semi-finished products and, ultimately, the quality indicators and shelf life of finished products $[15,17]$.

The processes of the fruit jelly products formation was studied in the works of such scientists as A.M. Dorohovych, V.F. Pertsevyi, V.I. Obolkina, I.O. Krapyvnytska, E.H. Iorhachev, Y.V. Kambulova, etc. [1,5-12]. However, there is no data on the effects of nanopowder supplements, in particular, of the "Magnetofood" food supplement on the structure formation of jelly pastes in the production of fruit jelly and further studies are necessary.

Therefore, studying the influence of the "Magnetofood" food supplement on the structural and mechanical properties of mold fruit jelly with various structure-forming additives is well-timed and relevant.

\section{Literature Data Analysis and Target Setting}

Fruit jelly products are useful and light confectionery products, thus, their assortment and level of consumption has increased in recent years [3]. Much of the fruit jelly products are made by foreign companies, for which reason the fruit jelly manufacturers must constantly improve the recipes and technologies, using a variety of food ingredients, supplements, improvers and technological methods [6-12,18-35].

In order to improve the structural and mechanical properties of jelly pastes, it is proposed to use pectic substances obtained from non-traditional raw materials, such as food industry waste (canning, wine-making, sugar-beet industries) and agriculture (seed-growing state farms, cotton growing, melon-growing) sectors [18,19]; 
as well as alternative raw materials: chitosan, vegetable, vegetable, and fruit and vegetable products [7,8,18-20].

Combined gel-forming systems for regulating the rheological and structural and mechanical properties of semi-finished and finished fruit jelly products are proposed, in particular the combination of gelatin and pectin, sulfated polysaccharides, gelatin - k-carrageenan, gelatin - LM pectin, [21-23]; pectin and hydrocolloids (Herbagel SW-010, ricogel 8100), LM pectin - kcarrageenan [23-25]; agar and Scanpro animal protein concentrate [26].

To improve the plastic strength of the jelly and the texture of fruit jelly products, various hydrogels are widely used in the production of fruit jelly and marmalade products, possessing the properties of thickeners, gelling agents and stabilizers - carrageenan and its sodium, potassium, ammonium salts, including furcellaran; xanthan, tara, guar gum, locust bean gum, xanthan gum, etc. $[25,27,28]$.

Numerous studies had been conducted to explore the effect of modifying supplements on the structural and mechanical properties of jellies: sodium carboxymethylcellulose (Na-CMC) and iron chloride to increase the ability of sulfate polysaccharides [22, 29]; sodium lactate, sodium citrate and glycerol in the amount of $(0,1-0,2) \%$ of the total weight to increase the gelatinous ability of red seaweed polysaccharides and, as a result, to reduce their content by $(35-40) \%$ [30,31]; mannitol or sodium alginate in the amount of $(0,08-0,09) \%$ to increase the strength of the jellt to (40-60) \% and to reduce the amount of agar (agaroid, furcellaran) used [32].

The most important factors in the formation of the quality of fruit jelly products is the correct selection and preparation of raw materials, compliance with the recipes and technological production flow diagram. Currently, Ukrainian manufacture of fruit jelly products mainly use two gelling agents: agar $(0.8-10) \%$ and pectin $(1.0-1.5) \%$. Agaroid (Black Sea agar) and furcellaran (estagar) are of limited prevalence $[2,9]$.

Introduction of gelling agents to the recipe yields a fairly strong jelly, the formation of which may be explained by the association of macromolecules or fragments with the formation of a three-dimensional network maintaining the liquid phase and providing resistance to external loads. The choice of gelling agents is very important for manufacturers, since it affects both the parameters of the technological process: the standard addition of other recipe components, use of appropriate equipment; and the texture properties of the product, and ultimately the quality indicators of the finished products $[8,33]$.

Among the factors shaping the consumer preferences in choosing the fruit jelly and marmalade products, texture is most significant [1,11,32,33]. Therefore, the rheological properties of the jelly pastes and the process of gelation based on the transition of the solution containing the gelling agent from its liquid fluid state to a semi-solid gel-like structure, are predetermining in the production technology of fruit jelly and marmalade. The structure, mechanical strength of the mold jelly pastes and, ultimately, the quality of the finished products and their stability during storage depend on the gelation process.

The use of and research in ingredients and food supplements, improvers, correcting the rheological properties of jelly pastes and forming the necessary structural and mechanical characteristics, is an important task in the fruit jelly technology, as it contributes to the development of resource-saving technologies, expanding the range, increasing shelf life, saving raw materials and reducing the cost of finished products.

Analysis of information sources [1-35] shows the lack of data on fruit jelly technologies using nanopowder additives, improving the structural and mechanical properties of jelly pastes and finished products. We have developed and proposed the "Magnetofood" food additive [TU U 10.8-2023017824-001:2018] as an additive improver for food systems. This is an ultra-fine powder with a large specific and highly active surface.

In food systems, "Magnetofood" exhibits deoxidizing, antioxidant, sorption, bacteriostatic, complexing, emulsifying, water-retentive, fat-holding, water-binding, stabilizing, structuring properties [13-17].

In this regard, it is relevant to study the rheological and structural and mechanical properties of jelly pastes with various structure-forming agents when introducing the "Magnetofood" food supplement into the recipe composition.

\section{Purpose and Objectives of Research}

The aim of the work is to study the structural and mechanical properties of mold fruit jelly with various structure-forming agents when introducing the "Magnetofood" food supplement into the recipe composition.

To achieve the goal, the following tasks were set:

to investigate the influence of the "Magnetofood" food supplement on:

- viscosity of test samples of jelly pastes on agar and pectin in the range of shear stress: $\gamma=(1,5-40) \mathrm{s}^{-1}$;

- effective viscosity of test samples of jelly pastes on agar and pectin at different temperatures;

- time and intensity of thixotropic destruction and recovery for test samples of jelly pastes on agar and pectin;

- strength of jellies for test samples of jelly pastes on agar and pectin;

- rate of structuring test samples of jelly pastes on agar and pectin;

- to establish a rational mass fraction of the "Magnetofood" food supplement in the fruit jelly formulations on agar and pectin.

\section{Statement of Basic Materials}

Object of research: technology of mold fruit jelly on agar and pectin. Subjects of research: for modeling test 
samples of jelly pastes, the following basic recipes were selected: Formulation No. 11 (mold fruit jelly on agar [DSTU 4333:2004]) in Table 1, Formulation No. 49 (mold fruit jelly on pectin [DSTU 4333:2004]) in Table 2 [2].

Preparation of test samples of jelly pastes. Weighted amounts of dry gelling agent (agar or pectin see Table 1 and Table 2), taking into account the amount of "Magnetofood" food supplement introduced (1.0 g, 1.5 $\mathrm{g}, 2.0 \mathrm{~g}$ per $1 \mathrm{~kg}$ of raw material) were added to $263 \mathrm{ml}$ of drinking water, the mixture was heated with thorough stirring until complete dissolution of the gelling agents and solvation of the "Magnetofood" food supplement particles. Following that, the sugar was added in accordance with the formulation and boiled down to achieving the dry matter content: (73-74)\% for agar and (70-72)\% for pectin. At the end of boiling, $262.7 \mathrm{~g}$ of molasses was added. The resulting syrup was cooled to the temperature of: $(50-60){ }^{\circ} \mathrm{C}$ for agar and $(76-80){ }^{\circ} \mathrm{C}$ for pectin (such temperatures for processing the jelly pastes are contingent upon different gelation temperatures of gelling agents), and stirred. After that, the structural and mechanical parameters in test samples of jelly pastes were determined.

Table 1 - Mold fruit jelly formulations on agar (control) and with different mass fractions of the "Magnetofood" food supplement

\begin{tabular}{|l|l|l|l|l|}
\hline \multirow{2}{*}{ Raw materials } & \multicolumn{4}{|l|}{$\begin{array}{l}\text { Raw material consumption per 1 ton } \\
\text { of finished products, kg }\end{array}$} \\
\cline { 2 - 5 } & $\begin{array}{l}\text { Sample } \\
1- \\
\text { control }\end{array}$ & $\begin{array}{l}\text { Sample } \\
2\end{array}$ & $\begin{array}{l}\text { Sample } \\
3\end{array}$ & $\begin{array}{l}\text { Sample } \\
4\end{array}$ \\
\hline $\begin{array}{l}\text { Sanding sugar } \\
\text { for sprinkling }\end{array}$ & 86.6 & 86.6 & 86.6 & 86.6 \\
\hline $\begin{array}{l}\text { Sanding sugar } \\
\text { for jelly }\end{array}$ & 525.6 & 525.6 & 525.6 & 525.6 \\
\hline Molasses & 262.7 & 262.7 & 262.7 & 262.7 \\
\hline Agar & 10.5 & 10.5 & 10.5 & 10.5 \\
\hline Citric acid & 11.8 & 11.8 & 11.8 & 11.8 \\
\hline $\begin{array}{l}\text { Various } \\
\text { essences }\end{array}$ & 1.6 & 1.6 & 1.6 & 1.6 \\
\hline Various dyes & 0.5 & 0.5 & 0.5 & 0.5 \\
\hline $\begin{array}{l}\text { "Magnetofood" } \\
\text { food } \\
\text { supplement }\end{array}$ & - & 1.0 & 1.5 & 2.0 \\
\hline
\end{tabular}

In the process of performing test works, standard and generally accepted research methods were used [3639]. Viscous and thixotropic characteristics were determined on the Reotest-2 rotation viscometer in accordance with the instructions [34]. The basis of the Reotest-2 working principle is measurement of onedimensional displacement, arising from the tangential displacement of the layers of the test sample. In this case, the measuring system of N/N cylinders was used.
Table 2 - Mold fruit jelly formulations on pectin and with different mass fractions of the "Magnetofood" food supplement

\begin{tabular}{|l|l|l|l|l|}
\hline \multirow{2}{*}{ Raw materials } & \multicolumn{4}{|c|}{$\begin{array}{l}\text { Raw material consumption per 1 ton } \\
\text { of finished products, kg }\end{array}$} \\
\cline { 2 - 5 } & $\begin{array}{l}\text { Sample } \\
5- \\
\text { control }\end{array}$ & $\begin{array}{l}\text { Sample } \\
6\end{array}$ & $\begin{array}{l}\text { Sample } \\
7\end{array}$ & $\begin{array}{l}\text { Sample } \\
8\end{array}$ \\
\hline $\begin{array}{l}\text { Sanding sugar } \\
\text { for sprinkling }\end{array}$ & 86.6 & 86.6 & 86.6 & 86.6 \\
\hline $\begin{array}{l}\text { Sanding sugar } \\
\text { for jelly }\end{array}$ & 718.9 & 718.9 & 718.9 & 718.9 \\
\hline Molasses & 262.7 & 262.7 & 262.7 & 262.7 \\
\hline Agar & 18.0 & 18.0 & 18.0 & 18.0 \\
\hline Citric acid & 12.0 & 12.0 & 12.0 & 12.0 \\
\hline $\begin{array}{l}\text { Various } \\
\text { essences }\end{array}$ & 10.0 & 10.0 & 10.0 & 10.0 \\
\hline Various dyes & 1.6 & 1.6 & 1.6 & 1.6 \\
\hline $\begin{array}{l}\text { "Magnetofood" } \\
\text { food } \\
\text { supplement }\end{array}$ & 0.6 & 0.6 & 0.6 & 0.6 \\
\hline $\begin{array}{l}\text { Sanding sugar } \\
\text { for sprinkling }\end{array}$ & - & 1.0 & 1.5 & 2.0 \\
\hline
\end{tabular}

Determination of the strength properties of test jelly samples was carried out on an AP-4/1 penetrometer by the cone dipping method with a cone opening angle of $30^{\circ}$ and $60^{\circ}$ using the standard method $[5,35,36]$. Average rate of structuring $V_{c m p}$ was found by the formula (1):

$$
V_{c m p}=\frac{\tau_{\max }-\tau_{0}}{B_{c m p}}
$$

where

$\tau_{\max }$ - maximum strength value, $\mathrm{kPa}$;

$\tau_{0}$ - initial strength value, $\mathrm{kPa}$;

$B_{c m p}-$ structuring duration, minutes.

\section{Findings}

An important structural and rheological characteristic affecting the course of the technological process, the quality of finished products and determining the behavior of the jelly paste at the stages of pipeline transportation, mixing and molding, is its viscosity. This indicator, determined by the forces of adhesion between the molecules, characterizes the resistance of the paste, its flow under the action of external forces and depends on many factors, such as dry matter content, composition and ratio of recipe components, temperature, etc. Previous studies have shown that the food additive "Magnetofood" affects the structural and mechanical properties of food systems, such as meat and dough $[13,14,17]$. In this regard, the effect of the "Magnetofood" food supplement on the viscosity of test samples of jelly pastes on agar and pectin (see Fig. 1, $a-b$ ) was studied. from fig. 1 it follows that the rheological curves of the prototypes of jelly masses in the interval of the considered shear rates are pseudo-plastic liquids, whose viscosity is a characteristic 
of the equilibrium state between the destruction and recovery processes.
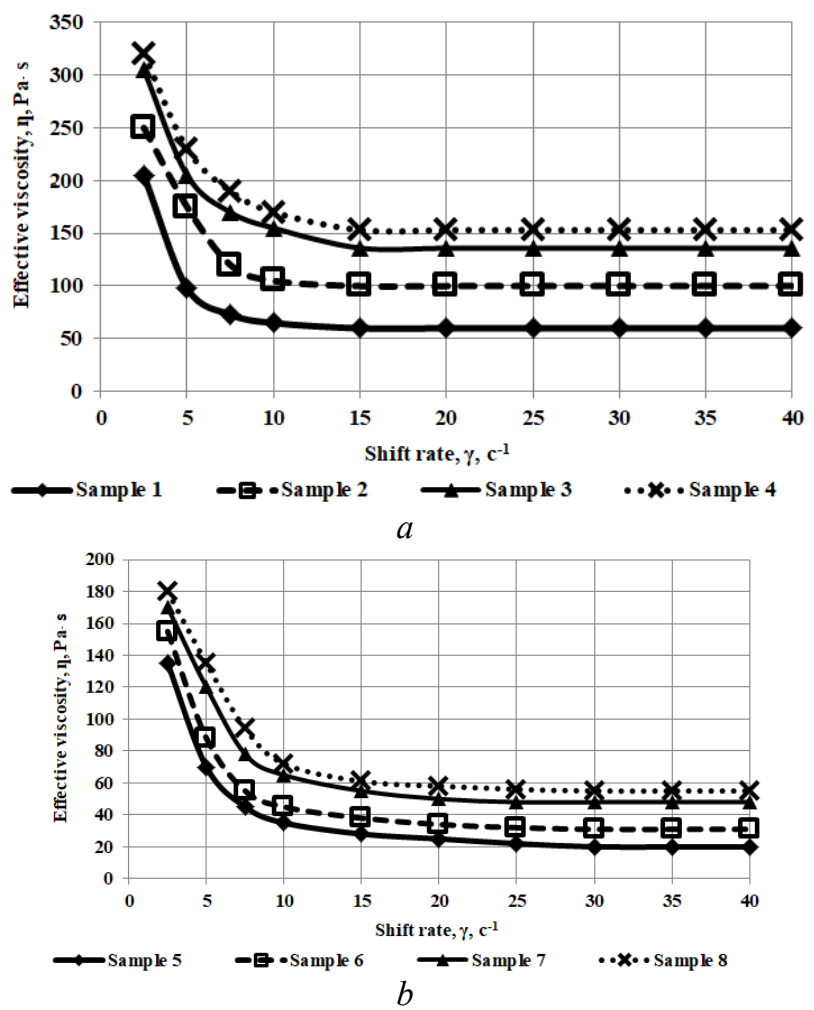

Fig. 1 - Effective viscosity of test samples of jelly pastes: $a$ - on agar; $b$ - on pectin

All test samples of jelly pastes (see Fig. 1, a-b) are characterized by a fairly high degree of structuring, and, consequently, the viscosity itself in the range of low shear stress: $\gamma=(1,8-9) \mathrm{s}^{-1}$, since the structure being destroyed by such a slow current has time to recover. As the shear rate increases, through asymmetric molecules taking an ordered position and being oriented in the direction of flow, the shear stress decreases, and, consequently, so does the viscosity. At the shift rate of $\gamma=(9,0-25) \mathrm{s}^{-1}$ for jelly pastes on agar and $\gamma=(7,5-12) \mathrm{s}^{-1}-$ on pectin, an intense destruction of the spatial framework is observed. With a further increase in shear rate, viscosity becomes minimal, characteristic of a destroyed structure, and constant regardless of the shear rate. It should be noted that the viscosity increases in the whole range of shear stress with the introduction of the "Magnetofood" food supplement in the amount of $(0.10-0.20) \%$ of the total weight of the raw material in all test samples of jelly pastes: $\gamma=(1,5-40) \mathrm{s}^{-1}$ by a factor of 2.9- for pastes on agar and by a factor of 1.85 - for pastes on pectin as compared to control samples. Moreover, the rational amount of the "Magnetofood" food supplement is $0.15 \%$, and a further increase has virtually no effect on the change in viscosity of the jelly pastes. The increase in the viscosity of the jelly pastes is caused by the ability of the "Magnetofood" food supplement to structure formation. In the process of jelly pastes - the food gel intermolecular, electrostatic and hydrophobic interactions between the saccharic components, gelling agents and nanoparticles of the "Magnetofood" food supplement are of significant importance. Due to this, a three-dimensional network is formed, built by hydrocolloid molecules, structured by the "Magnetofood" nanoparticles.

Since temperature is a factor that has the greatest effect on the fluidity of thermally unstable jelly pastes, the temperature regimes for studying the viscosity properties were chosen in accordance with the technological parameters of the jelly paste process at the introduction of flavoring, aromatic substances and dyes. The maintained temperature depended on the type of gelling agent used and exceeded its gelation temperature by $(5-7){ }^{\circ} \mathrm{C}:(82-5)$ ${ }^{\circ} \mathrm{C}$ for jelly pastes on pectin, $(52-5){ }^{\circ} \mathrm{C}$ for jelly pastes on agar, preventing the process of sucrose and gelling agent hydrolysis as a result of the introduction of acid, as well as the loss of aromatic substances [35,36].

During the technological process of fruit jelly production, the jelly paste while being pumped through the pipeline and mixed is subjected to mechanical stress, which affects its rheological properties and, as a result, the quality of the finished products. The occurring reverse destructions and recovery of connections between the components of the jelly paste, thixotropy, depend on its formulation. Therefore, most methods for determining the thixotropic properties are based on the determination of the rheological characteristics of jelly masses pastes in two states - those prior to destruction and afterwards [35].

However, based on the fact that the recommended parameters of the technological processes correspond to the shear rates at which the structure is destroyed $-\gamma=$ $5,4 \mathrm{~s}^{-1}$, the study of the influence of the mechanical processing duration on the rheological properties of test samples of jelly pastes, as well as the determination of the time of thixotropic recovery of their gel structure (see Fig. $2, a-b)$ is of particular interest.

It is seen from Fig. $2 a$ that an intensive decrease in viscosity of test samples of jelly pastes on agar occurs in the first (25-27) minutes of mechanical effect, after which an insignificant decrease in the values of this indicator is observed. So, the viscosity of the control sample (sample 1) within the time specified decreases from $99.5 \mathrm{kPa}$ to $10.5 \mathrm{kPa}$, that is, by a factor of 9.5 . As the "Magnetofood" food supplement content increases from $0.10 \%$ to $0.20 \%$, the thixotropic destruction of the jelly masses somewhat slows down in samples 2, 3, 4 with the content of the "Magnetofood" food supplement in the amount of $0,10 \% ; 0,15 \% ; 0,20 \%$, as a result of constant mechanical influence within 25 minutes, the viscosity decreases from $175 \mathrm{kPa}, 225 \mathrm{kPa}$ and $228 \mathrm{kPa}$ to $108 \mathrm{kPa}, 148 \mathrm{kPa}$ and $150 \mathrm{kPa}$ - that is, by a factor of 1.6 ; $1.5 ; 1.5$, respectively. After the mechanical effect ceases, a gradual recovery of the structure occurs within (15-20) minutes. Moreover, if we take the viscosity values at the initial time point prior to the structure destruction as $100 \%$, this indicator for the control sample (sample 1) decreases by $9.8 \%$ after its recovery, and on average by $3.8 \%$ for test samples with the "Magnetofood" food supplement (samples 2, 3, 4). 

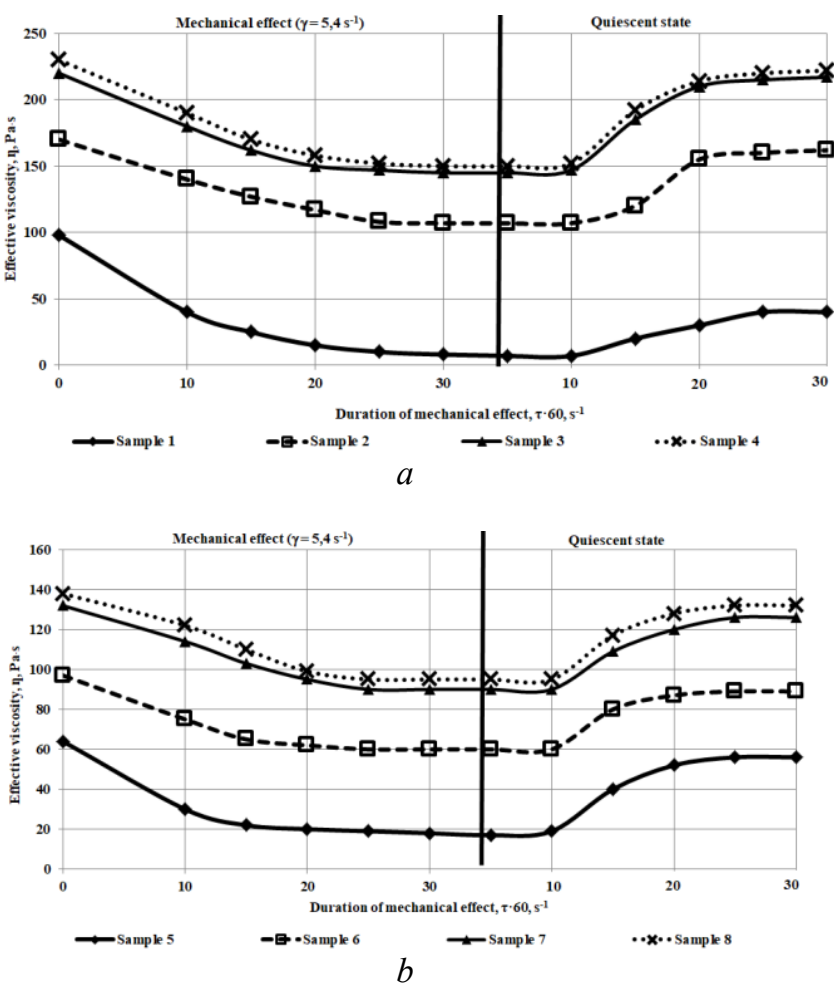

Fig. 2 - Dependence of the effective viscosity on the duration of mechanical effect with the subsequent quiescent state of the test samples of jelly pastes: $a$-on agar; $b$ - on pectin

Thus, the use of "Magnetofood" food supplement in the formulation of fruit jelly on agar slows down the processes of destruction by a factor of 1.1 and accelerates the processes of jelly structure recovery after mechanical effect ceases by $3.8 \%$, increasing its thixotropy ability by $7.5 \%$.

Time and intensity of thixotropic destruction and recovery for jelly pastes on pectin (see Fig. 2, b) are somewhat different. Thus, after (20-22) minutes of mechanical effect, viscosity of the jelly paste on pectin reaches its minimum value, and remains constant afterwards. At the same time, the time required for thixotropic recovery is (10-14) minutes. In accordance with research results, the introduction of the "Magnetofood" food supplement into the formulation affects the ability of jelly pastes to recover their original structure. So, viscosity of the control sample (sample 5) after mechanical effect with subsequent maturation is reduced by $9.4 \%$, and of the test samples $6,7,8$ with the addition of "Magnetofood" - by 3.3\%. That is, the use of the "Magnetofood" food supplement in the formulation of fruit jelly on pectin also slows down the destruction processes by a factor of 1.11 and speeds up the recovery processes of the jelly structure after the mechanical effect ceases by $3.82 \%$, increasing thixotropic ability by $6.0 \%$.

This occurs due to the fact that although the "Magnetofood" food supplement is not a surface active agent, however, "Magnetofood" nanoparticles are able to stabilize disperse systems such as emulsions and suspensions through their thickening and thixotropic properties, preventing the separation of the disperse system. A change in the current properties of a liquid disperse system in the presence of "Magnetofood" nanoparticles leads not only to its stabilization, but also to the formation of a certain consistency.

Changes in temperature and composition are reflected in the viscosity of test samples of jelly pastes. Therefore, the change in the rheological properties of test samples of jelly pastes depending on temperature was studied in order to determine the possibility of its regulation. In the hot jelly paste, the gelling molecules, forming different structures in an unpredictable manner, converge randomly as a result of Brownian motion and repel in the dispersion medium, which is an aqueous sugar solution. When the jelly paste is cooled to a temperature close to the gelation temperature, hydrogen bonds are formed between the macromolecules of the gelling agent and the process of formation of spatial structures occurs, the further aggregation of which is accompanied by emergence of jelly [11]. The temperature at which the process of gelation begins in the cooled jelly paste depends on the type of gelling agent used, the method of its production, etc. Fig. 3, $a-b$ presents dependence of the viscosity of test samples of jelly pastes on agar and pectin on temperature.
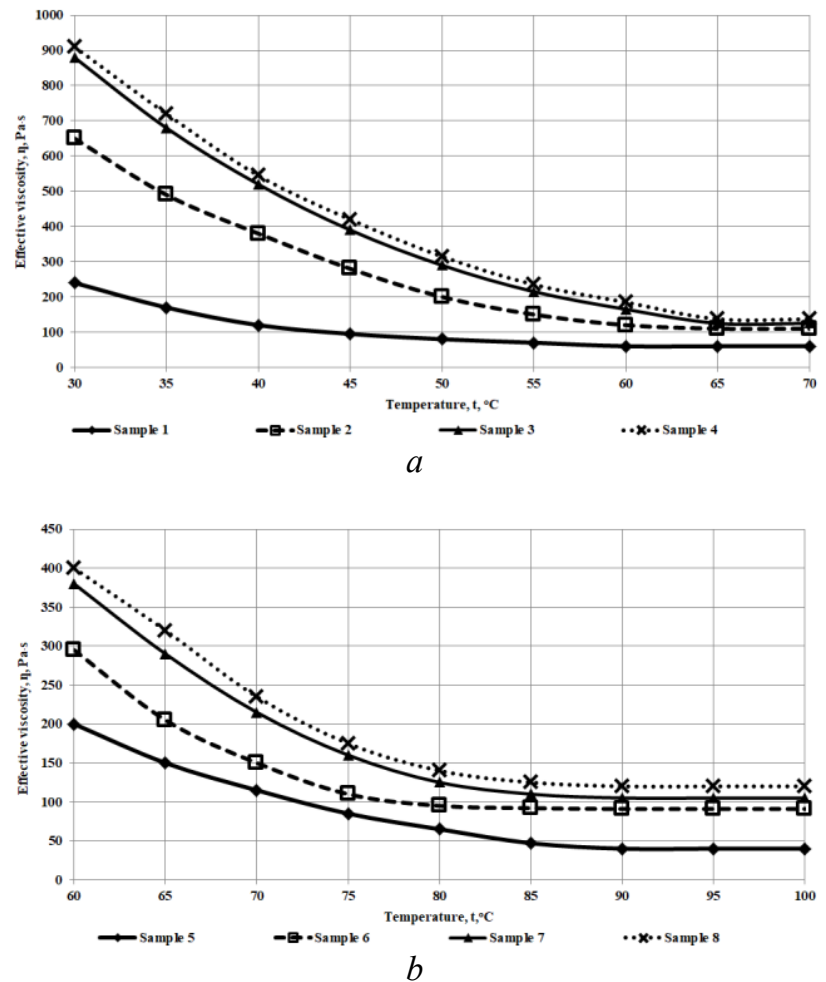

Fig. 3 -Dependence of viscosity on the temperature of test samples of jelly pastes. $a$-on agar; $b$ - on pectin

It follows from Fig. 3 that the effect of changes in component composition on viscosity is insignificant at high temperatures $(65-100){ }^{\circ} \mathrm{C}$ for test samples of jelly 
pastes on agar and $(85-100){ }^{\circ} \mathrm{C}$ for test samples on pectin, since the forces of intermolecular bonds between the recipe components of the system are weakened by their increased thermal vibrations. The speed and magnitude of the change in viscosity with decreasing temperature depends on the composition of the dispersion medium [37].

It follows from Fig. $3 a$ that the increase in viscosity of test samples of jelly pastes on agar when using the "Magnetofood" food supplement with a decrease in temperature becomes more pronounced. This increases the temperature effect on the rheological properties of jelly pastes. For example, the viscosity of the control sample 1 in the temperature range of (30-50) ${ }^{\circ} \mathrm{C}$ decreases 3.3 times, and the viscosity of samples 2,3 , 4 with the "Magnetofood" food supplement - only 3.25; 3.07; 2.89 times, respectively.

Similar changes are also observed in test samples 5-8 for pectin (Fig. 3, b): the viscosity of the control sample in the temperature range of $(60-80){ }^{\circ} \mathrm{C}$ decreases by a factor of 3.2 , and the viscosity of samples $6,7,8$ with the "Magnetofood" food supplement - only $3.1 ; 3.02$; 2.85 times, respectively.

It may be assumed that the use of the "Magnetofood" food supplement in test samples of jelly pastes leads to an increase in intermolecular bonds, which will be less affected by temperature, and less likely to break down during an elementary act of flow.

It follows from Fig. $3, a-b$ that the viscosity in test samples 5-8 on pectin is increased less with decreasing temperature compared to test samples 1-4 on agar. Perhaps, the number of active sites on the surface of pectin molecules insufficient for the formation of new intermolecular bonds contributes to this effect, causing an increase in the viscosity of the jelly paste with decreasing temperature [38].

At the temperature of $(50-55){ }^{\circ} \mathrm{C}$ for jelly pastes on agar and (75-80) ${ }^{\circ} \mathrm{C}$ for jelly pastes on pectin (see Fig. $3, a-b)$, an increase in viscosity is observed, which indicates that the structuring temperature is approached, which must be taken into account when mixing after addition of flavoring substances and when molding.

Considering the increase in the viscosity of test samples of jelly pastes on agar (2-4) and on pectin (6-8) when using the "Magnetofood" food supplement, the paste temperature must be increased to $(60 \pm 2.5)^{\circ} \mathrm{C}$ (for jelly pastes on agar) to approximate its value for control samples during such technological operations as mixing when adding flavor substances and molding. For jelly pastes on pectin, a temperature rise to $(80 \pm 2,5){ }^{\circ} \mathrm{C}$ is possible.

Study of Plastic Strength of Jelly Paste Test Samples. In the fruit jelly production technology, the determining factor of quality of a product is the process of gelation taking place as a result of the transition of the gelling agent from a liquid, fluid state to a semi-solid, jelly-like structure. This process is accompanied by a gradual increase in strength as a result of the emergence of homeopolar, ionic and associative bonds between the gelling agent molecules with the formation of a threedimensional network holding the liquid phase in its cells a solution of sugars that are part of the formulation. The structure, mechanical strength of the molded pastes and, as a result, the quality of the finished products and their stability during storage depend on the gelation process. At the same time, the structural and mechanical properties of the jelly, as well as the intensity of its formation in the maturing process, largely depends on the type and concentration of the gelling agents used, the composition and ratio of the recipe components, as well as on the temperature of the jelly paste during molding [39].

To study the influence of the "Magnetofood" food supplement and the temperature on the process of the formation of jelly pastes, a change in the strength of the jelly formation (see Fig. 4, $a-b$ ) was determined. The strength measurement was carried out 60 minutes after the formation of jelly pastes on agar and after 5 minutes - on pectin, which allows to achieve the level of structurization at which the penetration tool is dipped into the volume under study without violating its integrity. In determining the duration of the jelly paste maturation, we were guided by the fact that the strength of the jelly, at which it may be removed from the mold, cut and packaged, is $6.5 \mathrm{kPa}$ for jelly and marmalade pastes on agar and $4.5 \mathrm{kPa}-$ for pastes on pectin $[36,40]$.

Analysis of experimental data in Fig. $4, a-b$ shows that the control sample on pectin reaches the given value in 17 minutes at the temperature of jelly paste of $63{ }^{\circ} \mathrm{C}$, and in 90 minutes on agar, when the temperature inside the paste is $22^{\circ} \mathrm{C}$.
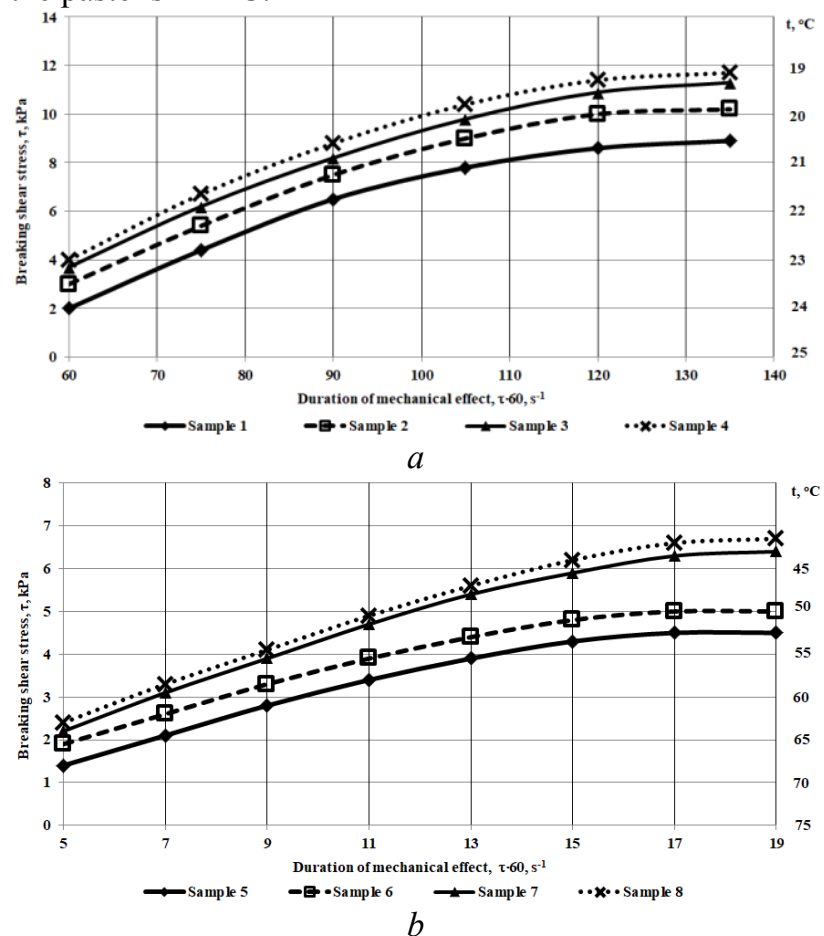

Fig. 4-Dependence of the breaking shear stress on the time of the mechanical effect of the gel-like layer of the test samples of jelly pastes. $a$-on agar; $b$ - on pectin 
As a result of determining the influence of the "Magnetofood" food supplement on the process of structure formation, it was established that in experimental samples of jelly pastes on agar (2-4) and on pectin (6-8) (see Fig. 4, $a-b$ ), addition of the "Magnetofood" food supplement in the amount of (0.10$0.20) \%$ of the total weight of raw materials leads to an increase in the strength of the jelly by (10-12)\% for agar and (7-9)\% for pectin as compared to the control samples $(1,5)$. Moreover, the rational amount of the "Magnetofood" food supplement amounts to $0.15 \%$ of the total weight of raw materials, since a further increase in the share of the "Magnetofood" food supplement to $0.20 \%$ did not have a significant effect on the plastic strength of the jelly.

The effect of the formulation on the intensity of the process of jelly formation was judged by the average rate of structuring (see Formula (1).

Table 3 shows the effect of the "Magnetofood" food supplement on the rate of structuring of test samples of jelly pastes.

Table 3 - Structuring speed of test samples of jelly

pastes
\begin{tabular}{|l|l|l|l|l|}
\hline $\begin{array}{l}\text { Indicators } / \\
\text { test samples }\end{array}$ & $\begin{array}{l}\tau_{0}, \\
\mathrm{kPa}\end{array}$ & $\begin{array}{l}\tau_{\max }, \\
\mathrm{kPa}\end{array}$ & $\begin{array}{l}\mathrm{t}_{\text {cmp },}, \\
\mathrm{min}\end{array}$ & $\begin{array}{l}V_{\text {cmp }}, \\
\mathrm{kPa} / \mathrm{min}\end{array}$ \\
\hline Test samples of jelly pastes on agar \\
\hline $\begin{array}{l}\text { Sample 1 - } \\
\text { control }\end{array}$ & 3.4 & 10.1 & 60 & 0.11 \\
\hline Sample 2 & 3.9 & 11.5 & 60 & 0.15 \\
\hline Sample 3 & 4.4 & 11.9 & 60 & 0.19 \\
\hline Sample 4 & 4.5 & 12.1 & 60 & 0.20 \\
\hline Test samples of jelly pastes on pectin \\
\hline $\begin{array}{l}\text { Sample 5 - } \\
\text { control }\end{array}$ & 1.8 & 5.6 & 12 & 0.28 \\
\hline Sample 6 & 2.3 & 6.7 & 12 & 0.37 \\
\hline Sample 7 & 2.8 & 7.2 & 12 & 0.47 \\
\hline Sample 8 & 2.9 & 7.4 & 12 & 0.49 \\
\hline
\end{tabular}

From the experimental data of Table 3 it follows that the addition of the "Magnetofood" food supplement in the amount of $(0.10-0.20) \%$ of the total weight of raw materials leads to an increase in the rate of structuring of the jelly pastes on agar by a factor of (1.1-1.6), and (1.31.7) on pectin. This is caused by the structuring and stabilizing properties of the "Magnetofood" food supplement: the ability to electrostatic and coordination interaction with the molecules of the gelling agents and the macromolecular aggregates of the system, forming the ordered spatial framework that strengthens gel-like structures. As a result, a good jelly texture is formed, which ensures high consumer properties and prolongs the shelf life, in particular, no moisture is released during storage.

Thus, the study of the structural and mechanical characteristics of the test samples of jelly pastes on agar and pectin showed that the "Magnetofood" food supplement contributes to the improvement of the gelforming ability of agar and pectin, the formation and further strengthening of the spatial framework of the gel in the course of samples' maturation. As a result, the jelly solidifies as a homogeneous monolithic and coagulation structure, and does not consist of jelly granules of various shapes and sizes. This improves the structural and mechanical characteristics of jelly and marmalade significantly.

Thus, the study of the structural and mechanical parameters of jelly pastes with various structure-forming agents confirms the hypothesis of stabilization of the structure of jelly pastes with the use of the "Magnetofood" food supplement. This also proves that the introduction of the "“Magnetofood" food supplement in the amount of $0.15 \%$ of the total weight of raw material at the gelling agent soaking stage, reduces its quantity: by $10 \%$ for agar and by $8 \%$ for pectin and also contributes to the strength of jelly and marmalade: by $10 \%$ for agar, by $8 \%$ for pectin.

The studies conducted and the results obtained form the basis for confirming the rational content of the "Magnetofood" food supplement in the formulations of mold fruit jelly $-0.15 \%$ of the total weight of raw material. Tables. 4 and 5 show the formulations of molded jelly "Ranok" (on agar) and "Veselka" (on pectin), respectively.

Table 4 -"Ranok" molded jelly formulation (on agar)

\begin{tabular}{|l|c|}
\hline \multicolumn{1}{|c|}{ Raw material } & $\begin{array}{c}\text { Raw material } \\
\text { consumption per 1 ton } \\
\text { of finished products,kg }\end{array}$ \\
\hline Sanding sugar for sprinkling & 86.6 \\
\hline Sanding sugar for jelly & 525.6 \\
\hline Molasses & 262.7 \\
\hline Agar & 9.5 \\
\hline Citric acid & 11.8 \\
\hline Various essences & 1.6 \\
\hline Various dyes & 0.5 \\
\hline "Magnetofood" food supplement & 1.5 \\
\hline
\end{tabular}

Table 5 - "Veselka" molded jelly formulation (on pectin)

\begin{tabular}{|l|c|}
\hline \multicolumn{1}{|c|}{ Raw material } & $\begin{array}{c}\text { Raw material } \\
\text { consumption per 1 ton } \\
\text { of finished products, kg }\end{array}$ \\
\hline Sanding sugar for sprinkling & 86.6 \\
\hline Sanding sugar for jelly & 718.9 \\
\hline Molasses & 262.7 \\
\hline Agar & 16.6 \\
\hline Citric acid & 12.0 \\
\hline Various essences & 10.0 \\
\hline Various dyes & 1.6 \\
\hline "Magnetofood" food supplement & 0.6 \\
\hline Sanding sugar for sprinkling & 1.5 \\
\hline
\end{tabular}

\section{Conclusions}

The results obtained confirm the hypothesis of stabilization of the structure of the jelly pastes with the use of the "Magnetofood" food supplement: 
-viscosity of the jelly pastes increases in all test samples of jelly pastes with the introduction of the "Magnetofood" food supplement in the amount of (0.10$0.20) \%$ of the total weight of raw material in the whole range of shear stress: $\gamma=(1,5-40) \mathrm{s}^{-1}$ by a factor of 2.9 for pastes on agar and 1.85- for pastes on pectin in comparison with control samples;

- use of the "Magnetofud" food supplement in test samples of jelly pastes slows down the processes of destruction of the jelly structure 1.1 times (on agar) and 1.11 times (on pectin), accelerates the processes of recovery of the jelly structure after the mechanical action ceases by $3.8 \%$ (on agar) and by $3.82 \%$ (on pectin), increases its thixotropy ability by $7.5 \%$ (on agar) and by $6.0 \%$ (on pectin);

- in test samples of jelly pastes with the use of the "Magnetofood" food supplement, the effect of temperature on the effective viscosity is on average slowed down by (50-75) $\mathrm{Pa} \cdot \mathrm{s}$ compared to control samples;

-introduction of the "Magnetofood" food supplement in test samples of jelly pastes in the amount of $(0.10-0.20) \%$ of the total weight of raw materials leads to an increase in the strength of jelly by $(10-12) \%$ for agar and (10-12)\% for pectin and to an increase in the rate of structuring of jelly pastes by a factor of (1.1-1.6) on agar, and (1.3-1.7) on pectin compared to control samples.

The rational content of "Magnetofood" food supplement in mold fruit jelly formulations was determined $-0.15 \%$ of the total weight of the raw material. Formulations of mold fruit jelly "Ranok" (on agar) and "Veselka" (on pectin) was developed.

\section{Список літератури}

1. Дорохович, А. М. Технологія галузі кондитерське виробництво. Курс лекцій / А. М. Дорохович, С. Г. Бондаренко, Л. М. Недсліна. - Київ:НУХТ, 2006. $110 \mathrm{c}$.

2. Иванушко, Л. С. Рецептуры на мармелад, пастилу и зефир / Л. С. Иванушко. - Москва: Пищевая промышленность, 1974. - 208 с.

3. Стасіневич, С. А. Ринок кондитерських виробів України: пропозиція і попит / С. А. Стасіневич, С. М. Валявський // Продукты \& ингредиентыл. - 2013. - № 1. - C. 14-17.

4. Сарафанова, Л. А. Применение пищевых добавок в кондитерской промышленности / Л. А. Сарафанова. СПб. Профессия, 2005. - 304 с.

5. Іоргачева, E. Г. Технологія кондитерського виробництва. Практикум / Е. Г. Іоргачева, О. В. Макарова, Л. В. Гордіснко, Г. В. Коркач. - Одеса: Сімекс-прінт, 2011. - 204 с.

6. Камбулова, Ю. В. Удосконалення технології мармеладу желейного 3 пониженим вмістом цукрі / Ю. В. Камбулова, Д. С. Матяс // Міжнародний науковий журнал "Інтернаука". - 2018. - №15. - 14 с.

7. Крапивницкая, И. А. Овощные и фруктово-овощные пектиносодержащие продукты в отделочных полуфабрикатах с желейной структурой / И. А. Крапивницкая, В. И. Оболкина, У. С. Йовбак // Кондитерское производство. - 2014. - № 5. - С. 33-34.
8. Иоргачева, Е. Г. Альтернативные виды сырья в технологии получения пастило-мармеладных изделий / Е. Г. Иоргачева, К. В. Аветисян, А. В. Куц // Хлібопекарська і кондитерська промисловість України. - 2009. - № 1. - C. 14-16.

9. Дорохович, А. М. Тиксотропія кондитерських агарових гелів / А. М. Дорохович, А. В. Мурзін, І. Л. Клепіков // Хлебный и кондитерский бізнес. - 2014. -6(19). - С.34-37.

10. Дорохович, А. М. Використання гідроколоїдів у кондитерському виробництві / А. М. Дорохович, В. І. Оболкіна, О. О. Кохан (Гавва), С. Г. Кияниця // Хлібопекарська і кондитерська промисловість України. - 2005. - № 2. - C. 9-11.

11. Перцевої Ф. В., Крапивницька І. О., Омельчук С. О. Наукові та практичні аспекти пектину i пектинопродуктів: монографія. Суми: Сумський національний аграрний університет, 2015. - 314 с.

12. Иоргачева, Е. Г. Регулирование качества желейного мармелада с измененным углеводным составом / Е. Г. Иоргачева, К. В. Аветисян // Восточно-Европейский журнал передовых технологий. - 2016. - Т. 2/11. - № 80 . - C. 48-56. - doi: 10.15587/1729-4061.2016.65768.

13. Ilyukha, N. G. Production technology and quality indices of a food additive based on magnetite / N. G. Ilyukha, I. V. Tsykhanovska, Z. V. Barsova, V. A. Kovalenko // East European Journal of Advanced Technologies. - 2010. - Vol. 6, No. 10 (48). - P. $32-35$.

14. Tsykhanovska, I. V. Development of technology of ryewheat bread "Kharkiv Rodnichok" with the addition of a multifunctional nutritional supplement "Magnetofood" / I. V. Tsykhanovska, O. V. Aleksandrov, V. V. Evlaz, T. A. Lazareva, K. V. Svidlo, T. B. Gontar // East European Journal of Advanced Technologies. - 2017. - Vol. 6, No. 11 (90). - P. 48 - 58. - doi: 10.15587/1729-4061.2017.117279.

15. Tsykhanovska, I. Substantiation of the interaction mechanism between the lipo- and glucoproteids of ryewheat flour and nanoparticles of the food additive "Magnetofood" / I. Tsykhanovska, A. Alexandrov, V. Evlash, T. Lazareva, O. Bryzytska // East European Journal of Advanced Technologies. - 2018. - Vol. 4 /11, No 94. - P. 61-68. - doi: 10.15587/1729-4061.2018.140048.

16. Tsykhanovska, I. Substantiation of the mechanism of interaction of carbohydrates of rye-wheat flour and nanoparticles of the polyfunctional food additive "Magnetofood" / I. Tsykhanovska, A. Alexandrov, V. Evlash, T. Lazareva, T. Yevlash // East European Journal of Advanced Technologies. - 2018. - Vol. 3 /11, No 93. - P. 59-68. - doi: 10.15587/1729-4061.2018.133373.

17. Tsykhanovska, I. Formation of the functional and technological properties of the beef minced meat by using the food ad-ditive on the nanopowder basis of double oxide of two- and trivalent iron / I. Tsykhanovska, L. Skurikhina, V. Evlash, L. Pavlotska // Ukrainian food journal. - 2018. - Vol. 7, Issue 3. - P. 379-396. - doi: 10.24263/2304-974X-2018-7-3-4.

18. Бабаходжаев, С. Ф. Мармелад на хлопковом пектине / С.Ф. Бабаходжаев // Пищевая промышленность. - 1991. - № 2. - С. 54 .

19. Прназарова, У. Пектиновые вещества из отходов пищевых производств / У. Прназарова, А. $\mathbf{X}$. Арифходжаев, Х. Т. Саломов // Пищевая промышленность. - 1991. - № 2. - С. 55.

20. Гурьянов, И. Д. Хитозан в производстве желейного мармелада / И. Д. Гурьянов, 3. И. Фаизрахманова, Д. И. Фаизрахманова // Вестник Казанского 
технологического университета. - 2014. - № 7. - С. 205-208.

21. Фощан, А. Л., Григоренко, А. М. Патент № 61370 UA, МПК А 23 L 1/ 06. Спосіб підвищення міцності драглів сульфатних полісахаридів, 2011. Бюл. № 14. 4 с.

22. Фощан, А. Л. Регулювання реологічних та структурномеханічніх властивостей желейних виробів та напівфабрикатів на основі комбінованих систем драгле утворювачів / А. Л. Фощан // Хлібопекарська $i$ кондитерська промисловість України. - 2010. - № 2. C. 29-30.

23. Гриненко, И. Г. Некоторые закономерности образования инулиновых гелей / И. Г. Гриненко, Р. И. Грушецкий, Л. М. Хомичак // Caxap: Научнотехнический и производственный журнал. - 2014. - № 11. - С. 54-55.

24. Шебершнева, Н. Н. Использование рикогеля 8100 в производстве желейного мармелада / Н. Н. Шебершнева // Кондитерское производство. - 2013. № $6 .-$ C. $15-16$.

25. Игнатова, Т. А. Использование гидрогелей каррагинанов в технологии желейных продуктов / Т. А. Игнатова, А. В. Подкорытова // Актуальные проблемы освоения биологических ресурсов мирового океана: материаль III Междунар. науч.-техн. конф. в 2 частях. Владивосток: Дальрыбвтуз. - 2014. - C.58-63.

26. Теймурова, А. Т. Розробка технологій желейної продукції 3 використанням концентратів тваринних білків: автореф. дис. канд. техн. наук. Харків: Харьківский державний університет харчування та торгівлі, 2010. 18 с.

27. Осипов, А. Пектины и каррагинаны для кондитерских изделий. Новые возможности традиционных ингредиентов / А. Осипов // Кондитерское производство. - 2012. - № 5. - С.18-19.

28. Маренкова, Т. I. Патент № 94598 UA, MПК A23L 1/00. Спосіб отримання мармеладу желейного формового на каппа-карагінані 3 якісно зміненими функціональнотехнологічними властивостями, 2014. Бюл. № 22. 6 с.

29. Артамонова, М. В., Лисюк, Г. М., Туз, Н. Ф. Технологія мармеладу желейного 3 використанням кріаспорошків рослинного походження: монографія. Харків: ХДУХТ, 2015. - 134 с.

30. Овсянникова, Л. Г. Использование кислых полисахаридов для сокращения расхода студнеобразователей из красных морских водоростей / Л. Г. Овсянникова // Сборник материалов науч.-техн. конференции «Прогрессивные технологии и оборудование пищевых производств». СПб: ГАХПТ, 1999. - C.183.

31. Евалева, В. В. Лактатсодержащие пищевые добавки и мармелад функционального назначения / В. В. Евалева, Т. М. Черпалова, Т. А. Никифорова // Кондитерское производство. - 2013. - № 6. - С. 13-16.

32. Свиридов, В. В. Влияние природы студнеобразователя на свойства пищевых студней / В. В. Свиридов, А. В. Банникова, Н. М. Птичкина // Известия вузов. Пищевая технология. - 2012. - № 1. - С. 59-61.

33. Шеховцова, Т. Г. Разработка технологии желейного мармелада с заданными потребительскими свойствами / Т. Г. Шеховцова, Ю. И. Сидоренко // Хранение и переработка сельхозсырья. -, 2008. - № 8. - С. 65-67.

34. Реотест: инструкция по эксплуатации. ГДР, 1978.

35. Косой, В. Д. Инженерная реология биотехнологических сред / В. Д. Косой, Я. И. Виноградов, А. Д. Малышев. - СПб.: ГИОРД, 2005. - 648 с.
36. Золотарева, Л. А. Структурообразователи и прочностные свойства желейных изделий / Л. А. Золотарева, К. В. Аветисян // Хлібопекарська $i$ кондитерська промисловість України. - 2007. - № 4. C. $40-41$.

37. Аймесон, А. Пищевые загустители, стабилизаторы, гелеобразователи / пер. С. В. Макарова / А. Аймесон. СПб.: ИД «Профессия», 2012. - 408 с.

38. Голубев, В. Н. Функциональные свойства пектинов и крахмала / В. Н. Голубев, С. Ю. Беглов, А. В. Поджуев // Пищевые ингредиентыл. Сырье и добавки. - 2000. - № 1. - C. 14-18.

39. Мазур, Л. М. Физико-химические процессы гелеобразования пектинов в пищевых технологіях / Л. М. Мазур, А. А. Олехнович // Caхар. - 2014. - 1. - С.2-5.

40. Карнаушенко, Л. И. Реологические свойства желейных масс / Л. И. Карнаушенко, Э. И. Погонцева, А. Д. Чмырь // Кондитерская и хлебопекарная промышленность. - 1981. - № 3. - С. 41-42.

\section{References (transliterated)}

1. Dorohovich, A. M., Bondarenko, Ye. G., Nedclina, L. M. Tehnologija galuzi konditers'ke virobnictvo. Kurs lekcij. Kiïv: NUHT, 2006, 110.

2. Ivanushko, L. S. Receptury na marmelad, pastilu i zefir. Moskva: Pishhevaja promyshlennost', 1974, 208.

3. Stasinevy`ch, S. A., Valyavs'ky`j, S. M. Ry`nok kondy`ters ‘ky`x vy`robiv Ukrayiny`: propozy`ciya i popy`t. Produkty \& y'ngredy 'enty, 2013, 1, 14-17.

4. Sarafanova, L. A. Primenenie pishhevyh dobavok v konditerskoj promyshlennosti. SPb. Professija, 2005, 304.

5. Iorgacheva, E. G., Makarova, O. V., Gordiyenko, L. V., Korkach, G.V. Texnologiya kondy`ters`kogo vy`robny`cztva. Prakty`kum. Odesa:Simeks-print, 2011, 204.

6. Kambulova, Yu. V., Matyas, D. S. Udoskonalennya texnologiyi marmeladu zhelejnogo $\mathrm{z}$ pony`zheny'm vmistom czukri. Mizhnarodny`j naukovy`j zhurnal “Internauka”, 2018, 15, 14.

7. Krapivnickaja, I. A., Obolkina, V. I., Jovbak, U. S. Ovoshhnye i fruktovo-ovoshhnye pektinosoderzhashhie produkty $\mathrm{v}$ otdelochnyh polufabrikatah $\mathrm{s}$ zhelejnoj strukturoj. Konditerskoe proizvodstvo, 2014, 5, 33-34.

8. Iorgacheva, E. G., Avetisjan, K. V., Kuc, A. V. Al'ternativnye vidy syr'ja $\mathrm{v}$ tehnologii poluchenija pastilomarmeladnyh izdelij. Xlibopekars `ka $i$ kondy`ters`ka promy 'slovist' Ukrayiny', 2009, 1, 14-16.

9. Doroxovy`ch, A. M., Murzin, A. V., Klepikov, I. L. Ty`ksotropiya kondy`ters`ky`x agarovy`x geliv. Hlebnyj $i$ konditerskij biznes, 2014, 6 (19), 34-37.

10. Doroxovy'ch, A. M., Obolkina, V. I., Koxan (Gavva), O.O., Ky`yany`cya, S. G. Vy`kory`stannya gidrokoloyidiv $\mathrm{u}$ kondy`ters`komu vy`robny`cztvi. Xlibopekars ka $i$ kondy 'ters 'ka promy slovist'Ukrayiny', 2005, 2, 9-11.

11. Percevoyi, F. V., Krapy`vny`cz'ka, I. O., Omel 'chuk, Ye. O. Naukovi ta prakty'chni aspekty pekty`nu i pekty`noproduktiv: monografiya. Sumy`: Sums`ky`j nacional`ny`j agrarny`j universy`tet, 2015, 314.

12. Iorgachova, K., Avetisian, K. Quality adjustment for jelly marmalade of a modified carbohydrate structure East European Journal of Enterprise Technologies, 2016, 2/11, 80, 48-56, doi: 10.15587/1729-4061.2016.65768.

13. Ilyukha, N. G., Tsykhanovska, I. V., Barsova, Z. V., Kovalenko, V. A. Production technology and quality indices of a food additive based on magnetite. East European Journal of Advanced Technologies, 2010, 6, 10 (48), $32-35$. 
14. Tsykhanovska, I. V., Aleksandrov, O. V., Evlaz, V. V., Lazareva, T. A., Svidlo, K. V., Gontar, T. B. Development of technology of rye-wheat bread "Kharkiv Rodnichok" with the addition of a multifunctional nutritional supplement "Magnetofood". East European Journal of Advanced Technologies, 2017, 6, No. 11 (90), 48 - 58.

15. Tsykhanovska, I., Alexandrov, A., Evlash, V., Lazareva, T., Bryzytska, O. Substantiation of the interaction mechanism between the lipo- and glucoproteids of ryewheat flour and nanoparticles of the food additive "Magnetofood". East European Journal of Advanced Technologies, 2018, 4/11, No 94, 61-68.

16. Tsykhanovska, I., Alexandrov, A., Evlash, V., Lazareva, T., Yevlash, T. Substantiation of the mechanism of interaction of carbohydrates of rye-wheat flour and nanoparticles of the polyfunctional food additive "Magnetofood". East European Journal of Advanced Technologies, 2018, 3/11, No 93, 59-68.

17. Tsykhanovska, I., Skurikhina, L., Evlash, V., Pavlotsk,a L. Formation of the functional and technological properties of the beef minced meat by using the food ad-ditive on the nanopowder basis of double oxide of two- and trivalent iron. "Ukrainian food yournal", 2018, 7, Issue 3, 379-396.

18. Babahodzhaev, S. F. Marmelad na hlopkovom pektine. Pishhevaja promyshlennost', 1991, 2, 54.

19. Prnazarova, U., Arifhodzhaev, A. H., Salomov, H. T. Pektinovye veshhestva iz othodov pishhevyh proizvodstv. Pishhevaja promyshlennost', 1991, 2, 55.

20. Gur'janov, I. D., Faizrahmanova, Z. I., Faizrahmanova, D. I. Hitozan v proizvodstve zhelejnogo marmelada. Vestnik Kazanskogo tehnologicheskogo universiteta, 2014, 7, 205208.

21. Foscan, A. L., Hryhorenko, A. M. Patent 61370 UA, MPK A $23 \mathrm{~L} \mathrm{1/} \mathrm{06.} \mathrm{Sposib} \mathrm{pidvyščennja} \mathrm{micnosti} \mathrm{drahliv}$ sul'fatnyx polisaxarydiv, 2011. Bjul. 14, 4.

22. Foscan, A. L. Rehuljuvannja reolohičnyx ta strukturnomexaničnix vlastyvostej želejnyx vyrobiv ta napivfabrykativ na osnovi kombinovanyx system drahle utvorjuvačiv. Xlibopekars'ka i kondyters'ka promyslovist' Ukrajiny, 2010, 2, 29-30.

23. Grinenko, I. G., Grusheckij, R. I., Homichak, L. M. Nekotorye zakonomernosti obrazovanija inulinovyh gelej. Sahar: Nauchno-tehnicheskij i proizvodstvennyj zhurnal, $2014,11,54-55$.

24. Shebershneva, N. N. Ispol'zovanie rikogelja 8100 v proizvodstve zhelejnogo marmelada. Konditerskoe proizvodstvo, 2013, 6, 15-16.

25. Ignatova, T. A., Podkorytova, A. V. Ispol'zovanie gidrogelej karraginanov $\mathrm{v}$ tehnologii zhelejnyh produktov. Aktual'nye problemy osvoenija biologicheskih resursov mirovogo okeana: materialy III Mezhdunar. nauch.-tehn. konf. $v 2$ chastjah. Vladivostok: Dal'rybvtuz, 2014, 58-63.
26. Tejmurova, A. T. Rozrobka texnolohij želejnoji produkciji z vykorystannjam koncentrativ tvarynnyx bilkiv: avtoref. dys. kand. texn. nauk. Xarkiv: Xar'kivskyj deržavnyj universytet xarčuvannja ta torhivli, 2010, 18.

27. Osipov, A. Pektiny i karraginany dlja konditerskih izdelij. Novye vozmozhnosti tradicionnyh ingredientov. Konditerskoe proizvodstvo, 2012, 5, 18-19.

28. Marenkova, T. I. Patent 94598 UA, MPK A23L 1/00. Sposib otrymannja marmeladu želejnoho formovoho na kappa-karahinani $\mathrm{z}$ jakisno zminenymy funkcional'notexnolohičnymy vlastyvostjamy, 2014. Bjul. 22, 6 .

29. Artamonova, M. V., Ly`syuk, G. M., Tuz, N. F. Texnologiya marmeladu zhelejnogo z vy`kory`stannyam kriasporoshkiv rosly'nnogo poxodzhennya: monografiya. Xarkiv: XDUXT, 2015, 134.

30. Ovsjannikova, L. G. Ispol'zovanie kislyh polisaharidov dlja sokrashhenija rashoda studneobrazovatelej iz krasnyh morskih vodorostej. Sbornik materialov nauch.-tehn. konferencii «Progressivnye tehnologii i oborudovanie pishhevyh proizvodstv». SPb: GAHPT, 1999, 183.

31. Evaleva, V. V., Cherpalova, T. M., Nikiforova, T. A. Laktatsoderzhashhie pishhevye dobavki i marmelad funkcional'nogo naznachenija. Konditerskoe proizvodstvo, 2013, 6, 13-16.

32. Sviridov, V. V., Bannikova, A. V., Ptichkina, N. M. Vlijanie prirody studneobrazovatelja na svojstva pishhevyh studnej. Izvestija vuzov. Pishhevaja tehnologija, 2012, 1, 59-61.

33. Shehovcova, T. G., Sidorenko, Ju. I. Razrabotka tehnologii zhelejnogo marmelada s zadannymi potrebitel'skimi svojstvami. Hranenie $i$ pererabotka sel'hozsyr'ja, 2008, 8, 65-67.

34. Reotest: instrukcija po jekspluatacii. GDR, 1978.

35. Kosoj, V. D., Vinogradov, Ja. I., Malyshev, A. D. Inzhenernaja reologija biotehnologicheskih sred. $\mathrm{SPb}$.: GIORD, 2005, 648 .

36. Zolotareva, L. A., Avetesjan, K. V. Strukturoobrazovateli i prochnostnye svojstva zhelejnyh izdelij. Hlibopekars'ka $i$ konditers'ka promislovist' Ukraïni, 2007, 4, 40-41.

37. Ajmeson, A. Pishhevye zagustiteli, stabilizatory, geleobrazovateli / per. S. V. Makarova. SPb.: ID «Professija», 2012, 408.

38. Golubev, V. N., Beglov, S. Ju., Podzhuev, A. V. Funkcional'nye svojstva pektinov i krahmala. Pishhevye ingredienty. Syr'e i dobavki, 2000, 1, 14-18.

39. Mazur, L. M., Olehnovich, A. A. Fiziko-himicheskie processy geleobrazovanija pektinov $\mathrm{V}$ pishhevyh tehnologijah. Sahar, 2014, 1, 2-5.

40. Karnaushenko, L. I., Pogonceva, Je. I., Chmyr', A. D. Reologicheskie svojstva zhelejnyh mass. Konditerskaja $i$ hlebopekarnaja promyshlennost', 1981, 3, 41-42.

\section{Відомості про авторів (About authors)}

Iryna Tsykhanovska - Candidate of Chemical Sciences, Ukrainian Engineering Pedagogics Academy, Associate Professor of the Food and Chemical Technologies Department; Kharkiv, Ukraine; ORCID: 0000-0002-9713-9257; e-mail: Cikhanovskaja@gmail.com.

Цихановська Ірина Василівна - кандидат хімічних наук, Українська інженерно-педагогічна академія, доцент кафедри харчових та хімічних технологій; м. Харків, Україна; ORCID: 0000-0002-9713-9257; e-mail: Cikhanovskaja@gmail.com.

Viktoriia Yevlash - Doctor of Technical Sciences, Professor, Kharkiv State University of Food Technology and Trade, Professor, Head of the Chemistry, Microbiology and Food Hygiene Department, Kharkiv, Ukraine; ORCID: 0000- 0001-7479-1288, e-mail: evlashvv@gmail.com. 
Свлаш Вікторія Владленівна - доктор технічних наук, професор, Харківський державний університет харчування та торгівлі, професор, завыдувач кафедри хімії, мікробіології та гігієни харчування, м.Харків, Україна; ORCID: 0000-0001-7479-1288, e-mail: evlashvv@gmail.com.

Barna Khamitova - Candidate of Technical Sciences, M. Auezov South Kazakhstan State University, Associate Professor of Technology and Food Safety Department, Shymkent, Kazakhstan, ORCID: 0000-0002-4435-3345, e-mail: barno_007@mail.ru.

Хамімова Барна Махаматовна - кандидат технічних наук, Південно-Казахстанський державний університет ім. М. Ауезова, доцент кафедри технології та безпеки харчових продуктів,м. Шимкент, Казахстан, ORCID: 0000- 0002-4435-3345, еmail: barno_007@mail.ru.

Klara Urazbaieva - Candidate of Technical Sciences, M. Auezov South Kazakhstan State University, Associate Professor, Head of the Food Engineering Department, Shymkent, Kazakhstan, ORCID: 0000-0002-6922-5940, e-mail: klara_abdrazak@mail.ru.

Уразбаєва Клара Абдиразаховна - кандидат хімічних наук, Південно-Казахстанський державний університет ім. М. Ауезова, доцент, завідувач кафедри харчова інженерія,м. Шимкент, Казахстан, ORCID: 0000-0002-6922-5940, e-mail: klara_abdrazak@mail.ru.

Oleksandr Aleksandrov - Candidate of Chemical Sciences, Ukrainian Engineering Pedagogics Academy, Associate Professor, Food and Chemical Technology Department; Kharkiv, Ukraine; ORCID: 0000-0003-3592-285X; e-mail: alexandrov.a.v.a.v@gmail.com.

Александров Олександр Валентинович - кандидат хімічних наук, Українська інженерно-педагогічна академія, доцент завідувач кафедри харчових та хімічних технологій; м.Харків, Україна; ORCID: 0000-0003-3592- 285X; e-mail: alexandrov.a.v.a.v@gmail.com.

Nataliia Kaida - Ukrainian Engineering Pedagogics Academy, Assistant Professor of Food and Chemical Technology; Kharkiv, Ukraine; ORCID: 0000-0002-6856-8247; e-mail: karonac@gmail.com.

Кайда Наталія Серхї̈вна -Українська інженерно-педагогічна академія, асистент кафедри харчових та хімічних технологій; м.Харків, Україна; ORCID: 0000-0002-6856-8247; e-mail: karonac@gmail.com.

Please cite this article as:

Tsykhanovska, I., Yevlash, V., Khamitova, B., Urazbaieva, K., Aleksandrov, O., Kaida, N. Influence of the "magnetofood" food supplement on the structural and mechanical properties of molded fruit jelly with various structure-forming agents. Bulletin of NTU "KhPI". Series: New solutions in modern technologies. - Kharkiv: NTU "KhPI", 2019, 5 (1330), 175-186, doi:10.20998/2413-4295.2019.05.23.

Будь ласка, посилайтесь на ию статтю наступним чином:

Цихановська, І. В. Вплив харчової добавки “магнетофуд” на структурно-механічні властивості формового желейного мармеладу з різними структуроутворювачами / І. В. Цихановська, В. В. Свлаш, Б. М. Хамітова, К. А. Уразбасва, О. В. Александров, Н. С. Кайда // Вісник НТУ «ХПІ», Серія: Нові рімення в сучасних технологіях. - Харків: НТУ «ХПІ». - 2019. - № 5 (1330). - C. 175-186. - doi:10.20998/2413-4295.2019.05.23.

Пожалуйста, ссылайтесь на эту статью следующим образом:

Цихановская, И. В. Влияние пищевой добавки “магнетофуд” на структурно-механические свойства формового желейного мармелада с разными структурообразователями / И. В. Цихановская, В. В. Евлаш, Б. М. Хамитова, К. А. Уразбаева, А. В. Александров, Н. С. Кайда // Вестник НТУ «ХПИ», Серия: Новые решения в современных технологиях. Харьков: НТУ «ХПИ». - 2019. - № 5 (1330). - С. 175-186. - doi:10.20998/2413-4295.2019.05.23.

АННОТАЦИЯ Одной из актуальных проблем современной кондитерской промышленности является разработка ресурсои энергосберегающих технологий для производства высококачественных мармеладо-пастильных изделий с увеличенным сроком годности. Предлагается использование минеральной пищевой добавки “Магнетофуд”, которая обладает высоким функиионально-технологическим потенциалом и может как самостоятельно формировать структурно-механические свойства желейных масс, так и влиять на гелеобразователь, вступая с ним в химические и электростатические взаимодействия. Поэтому, пищевая добавка "Магнетофуд” може влиять сразу на несколько технологических свойств в пищевой желейной системе: быть стабилизатором, загустителем, студнеобразователем, при этом улучшая качество, потребительские свойства и продляя сроки хранения формового желейного мармелада. Целью исследования является улучшение структурно-механических свойств формового желейного мармелада путем введения пищевой добавки «Магнетофуд». Во время проведения структурно-механических (вязкостних и тиксотропных характеристик на ротационном вискозиметре реотест-2, прочности на пенетрометры AP-4/1) исследований были использованы общепринятые и стандартные методики. Установлено, что введение пищевой добавки “Магнетофуд” в желейные массы в количестве 0,15\% к массе сырья улучшает консистенцию, структуру, прочность и форму: повышается степень структурирования и вязкость желейных масс во всем диапазоне напряжения сдвига $\left(1,5-40 c^{-1}\right)$ в 2,9 раза - для масс на агаре и в 1,85 раз - для масс на пектине; замедляется влияние температуры на эффективную вязкость желейных масс в среднем на (50-75) Па.с, а также прочессы разрушения в 1,1 раза и ускоряются процессы восстановления желейной структуры после прекращения механического воздействия на 3,8\%, повышая её способность к тиксотропии на 7,5\% 6 желейных массах на агаре и на 6,0\% - на пектине; увеличивается прочность студня на агаре на (10-12)\%, на пектине - на (7-9)\%; возрастает скорость структурирования желейных масс на агаре в 1,3-1,7 раз, а на пектине в 1,1-1,6 раз.

Ключевые слова: желейный мармелад; желейные массы; пищевая добавка “Магнетофуд”; структурно-механические свойства

Поступила (received) 16.02.2019 